\title{
DISCURSIVE POWER AND THE INTERNATIONALIZATION OF UNIVERSITIES IN BRITISH COLUMBIA AND ONTARIO
}

\author{
CONRAD KING
KWANTLEN POLYTECHNIC UNIVERSITY
}

\begin{abstract}
Universities rationalize internationalization according to paradigms that emerge from different contexts. With the advent of internationalization strategies by federal and provincial governments, what effect do government ideas have on Canadian universities? This article evaluates the discursive power of government, and its role in discourse communities pertaining to higher education internationalization. Employing a discursive institutionalist framework and qualitative research design, I evaluated discursive content at 16 Tier 1 and 2 universities in British Columbia and Ontario. The findings indicate that governments have had weak ideational influence over the past decade, especially at universities with a global or national orientation. Many of these universities have been undergoing a subtle shift in their internationalization rationales-although not all, and not at the same pace. Yet some Canadian universities have increasingly "looked within" to rationalize internationalization, because their discourse communities are dominated by internal voices more concerned with organizational context than global competitiveness.
\end{abstract}

Keywords: internationalization, internationalization rationales, discursive institutionalism

\section{Résumé}

Les universités justifient l'internationalisation en fonction de paradigmes qui émergent de différents contextes. Avec la venue de stratégies d'internationalisation de la part du gouvernement fédéral et des gouvernements provinciaux, quels sont les effets des idées gouvernementales sur les universités canadiennes? Cet article évalue le pouvoir discursif du gouvernement, et le rôle de celui-ci au sein des communautés discursives en ce qui concerne l'internationalisation dans l'enseignement supérieur. En utilisant le cadre de l'institutionnalisme discursif et un plan de recherche qualitatif, nous analysons le contenu discursif dans seize universités de première et deuxième catégories en Colombie-Britannique et en Ontario. Les conclusions indiquent que les gouvernements ont eu une faible influence idéationnelle au cours de la dernière décennie, particulièrement dans les universités ayant une orientation internationale ou nationale. Plusieurs de ces universités ont connu un changement subtil en ce qui concerne leur approche de l'internationalisation, quoique ce changement se soit effectué à des vitesses différentes, et pas partout. En outre, quelques universités canadiennes justifient l'internationalisation en fonction du contexte organisationnel plutôt que de la compétitivité internationale en raison de la prédominance des voix internes au sein de leurs communautés discursives.

Mots-clés : internationalisation, justifications de l'internationalisation, institutionnalisme discursif

\section{Introduction}

In many countries, public policies for higher education (HE) have a profound effect on the thinking of university administrators. In Canada, federal and provincial governmental strategies for HE internationalization have emphasized the market for international students, and Canada's global competitiveness in higher education.
These strategies could provide governments with ideational power to alter or reinforce university rationales for internationalization. One way to evaluate the effect of government policies is to examine the responsiveness of Canadian universities when they discuss and justify internationalization. What effect does government policy have on the internationalization rationales deployed by Canadian universities? Do university leaders adopt 
the paradigms suggested by government, or do they get their ideas about internationalization elsewhere?

To answer these research questions, I examined the dynamics of internationalization at 16 Tier 1 and 2 universities in British Columbia and Ontario. Through interviews with key policy interlocuters at these universities, I evaluated how discursive power was unevenly distributed at the organizational level. Some policy actors can shape the ideational content of internationalization using compelling discourses and their position within a discursive community. Yet governments, despite their political authority, have not been especially influential as sense-makers amongst larger, more globalized universities. When it comes to more recent internationalization efforts, it has been the smaller, more regional universities that tended to emulate the competitiveness paradigm put forward by provincial and federal governments. ${ }^{1}$

Using discursive institutionalism as a theoretical framework, and an interpretivist methodology, this study theorizes about the relationship between discursive power and rationales for HE internationalization. The research findings suggest that there is a subtle paradigm shift occurring within Canadian universities, regarding the ways that senior leadership think about internationalization. Ideas about internationalization are moving away from a competitiveness paradigm, and towards a social responsibility paradigm (although not every university, and not at the same pace). I make two arguments about why this is happening. First, that the governments of British Columbia (B.C.), Ontario, and Canada have weak discursive influence on university-level rationalizations for internationalization, especially for larger universities with a national or global orientation. Second, universities where internationalization is highly institutionalized are now looking within to better understand their place and purpose as an organization. Given the disparate ways to think about internationalization, and the profound consequences of internationalization choices, university leaders are becoming more attentive to organizational contexts and internal voices during the development of internationalization.

This article begins by assessing what we know about the formulation of university internationalization policies, describing rationales for internationalization at different levels of thinking. The subsequent two sections explain how the theoretical framework was developed, and the methods of analysis. The penultimate section elaborates my findings on discursive content and discourse communities for HE internationalization at these 16 universities. The conclusion sums up the arguments and proposes areas for future investigation.

\section{Internationalization at Canadian Universities: Context and Background}

Canadian universities have been rapidly internationalizing over the past two decades. By one measure-international student recruitment-Canada is among the fastest growing internationalizers in the world. ${ }^{2}$ Yet internationalization is not just about student mobility and recruitment of fees-paying students, it is also a "process of integrating an international, intercultural or global dimension into the purpose, functions or delivery of post-secondary education" (Knight, 2004, p. 11). Jane Knight has since expressed concern that internationalization "has become a catch-all phrase used to describe anything and everything remotely linked to the global, intercultural or international dimensions of higher education and is thus losing its way" (Knight, 2014, p. 76). Rather than revise our definition of internationalization, Knight proposed a reconsideration of the fundamental priorities which underpin it (Knight, 2014). A useful starting point is to recognize that internationalization rationales emerge from different contexts, and at different levels of thinking. At the macro-level, the broader environmental context becomes most prevalent, often accompanied by a competitiveness paradigm. Meso-level thinking addresses the narrower purposes for specific organizations (i.e., their mission and community), while the micro-level is concerned with the preferences or beliefs of actors within that community (Seeber et al., 2016). At the meso- and micro-levels, the organizational context becomes paramount: the broader sectoral environment still matters, but it becomes the backdrop for-perhaps even instrumental to-specific organizational rationales for internationalization. Below, I elaborate on the literatures for each context.

\section{Environmental Context (Macro-level Rationales)}

At the highest analytical level, one can understand a uni- 
versity as an institution operating within, and influenced by, a global educational culture. From this perspective, cross-border activities are a manifestation of world society-universities operate within an organizational field that seems to transcend the nation-state (Buckner, 2019; Meyer et al., 1997; Meyer \& Rowan, 1977). Where formerly this phenomenon drove a global movement toward the massification of higher education, since the 1990s, universities have increasingly been implicated in neo-liberal reforms that commodify knowledge, conveyed through terminology like academic capitalism or the great brain race (Boli et al., 1985; Olssen \& Peters, 2005; Slaughter \& Rhoades, 2004; Wildavsky, 2012). Whatever the direction of change, environmental pressure to conform to global best practice encourages organizational isomorphism, either through lesson-drawing or simply emulation (Dimaggio \& Powell, 1983). Moreover, the more globally-attuned a university is-such as sensitivity to international rankings-the more likely that the university will actively seek global legitimacy as an end in itself (Seeber et al., 2016). As an environmental factor, the current global educational culture suggests that university internationalization strategies are increasingly converging on economic rationales and increasing competitiveness (Marginson, 2013). However, significant variation in rationales and priorities continues to persist.

While there has been a degree of marketization across many HE systems-for countries within the Organisation for Economic Co-operation and Development, at any rate-governments and other buffer institutions continue to shape priorities for higher education internationalization. The result is a persistence of varieties of academic capitalism at the macro-level (Schulze-Cleven \& Olson, 2017). Although national cultures can also have a countervailing effect on global convergence dynamics (see Clark, 1983), the national context is now primarily understood in terms of government policy. Public policies can enable or constrain institutional decision making, where governments can create regulatory frameworks regarding the (national) mission of higher education, funding, or other policy areas with spillover effects into education (such as foreign policy, immigration or labour market policies). In the logic of organizational sociology, one could conceive of government policy as coercive isomorphism-it compels universities to act in certain ways vis-à-vis regulation or legislation. Increasingly, however, governments are moving towards coordinative policies, emphasizing horizontal network governance over hierarchical command-and-control forms of regulation. This style of governance allows government to steer organizational behaviour by influencing belief systems and incentivizing particular actions. Numerous cross-national studies have demonstrated that government policies shape university behaviour when it comes to internationalization (Crăciun, 2018; Enders, 2004; Helms \& Rumbley, 2017; Helms et al., 2015; Luijten-Lub et al., 2005; Teichler, 2004), while others argue that national contexts and government policies seem to matter less and less (Seeber et al., 2016). What seems clear is that everywhere we see the state trying to come back in to the HE sector. Governments are pushing universities to be more competitive, as well as cognizant of the economic benefits of internationalization, because "internationalization is an increasingly important strategic priority not only for institutions but also for governments, which are increasingly aware of the importance of universities in supporting national and regional competitiveness" (Wilson, 2013, p. 30). The "business" of international education is now reinforced by a global rankings culture and government policies.

What of Canada? Do government policies strongly affect how Canadian universities internationalize? For over two decades Canadian governments at every level, and from different ruling parties, have prioritized inbound student mobility as the primary mode of internationalization. The federal government has exhibited strong performance of neo-liberalism in its HE internationalization strategies, and Global Affairs Canada has made numerous attempts to coordinate $\mathrm{HE}$ internationalization going back to the 1990s (Government of Canada, 2014; Trilokekar, 2009; Viczko \& Tascón, 2016). Provincial governments proffer similar policy rationales for internationalization, citing reasons such as competitiveness of local industries, international students boosting local economies, universities as a pipeline to the labour market, and the opportunity to export educational services (British Columbia Ministry of Education, 2012; Council of Ministers of Education, Canada [CMEC], 2011; Ontario Ministry of Advanced Education and Skills Development, 2018). Yet the actual effects of government policy on university rationales remains unclear. On one hand, it is not clear if government policies have actually induced higher student numbers. "Governments are assumed to be consistently and intentionally pursuing a positional advantage through public policy in the global competition 
for talent" (Sá \& Sabzalieva, 2018, p. 232), but tellingly, the same authors observe that actual numerical growth in international students has been "decoupled from political and policy changes" (p. 232) in Canada. Perhaps inbound student numbers have been increasing in spite of (rather than because of) government policy. On the other hand, it is also not clear if government policies influence the rationales for internationalization, among university decision makers. This needs further research.

\section{Organizational Context (Meso- and Micro-level Rationales)}

There are several meso-level factors which influence how universities internationalize. Specific institutional characteristics such as size, geographic location, sources of funding, and degree of emphasis on each primary mission (i.e., teaching and research) have all been shown to influence the internationalization priorities of universities (Seeber et al., 2016; Stensaker et al., 2019). We might anticipate differences in rationales along these lines, perhaps especially evident in how universities conceive of their third mission (i.e., service to the broader community). Who these external communities are (at the global, national, or regional level), and how they are served (in terms of integration into the economy versus integration into a societal or cultural context) remains disparate. Yet, controlling for some of the major institutional characteristics, how to account for some convergent trends in thinking about internationalization? For example, among public-funded, comprehensive universities (i.e., with an emphasis on both teaching and research), we see widespread recognition of the importance of internationalization for research reputation and for students' learning experience. Internationalization strategies published by Canadian Tier 1 and 2 universities publicly acknowledge these rationales. This could simply be a reflection of attention to environmental context, but we should also investigate how university communities view themselves, and how they view their university's more specific organizational context.

A notable aspect of research on organizational context is that the internal structures of decision-making-intra-organizational dynamics at the micro-levelappear to matter (Seeber et al., 2016). Yet how these institutional structures matter needs further investigation. On the one hand are sociological explanations that emphasize the importance of culture as a kind of congealed institution. In a comparative case study of two American universities, Agnew and VanBalkom (2009) found that coherent internationalization was the result of value-congruency between institutional mission and formal policy, as well as between formal policy and the lived practice of students and (especially) faculty. Senior leadership with a clear sense of their university's mission in relation to external communities, and a deep understanding of their internal constituencies, were more culturally ready to adopt new internationalization mandates. On the other hand, rational choice institutionalism suggests that decision-making structures are only constraints or enablers for internal actors to achieve their preferred forms of internationalization. As an example of this approach, Seeber et al. (2016) found correlation between internal actors' assumed preferences and particular internationalization rationales, and that these internal dynamics-as well as meso-level organizational goalswere a stronger predictor than national context for the form of internationalization. However, these authors also found no correlation between the preferences of senior leadership and particular forms of internationalization. Either senior leadership did not matter, or their internationalization preferences were not fixed and given. We know that senior leaders matter because they must make policy choices, whether those choices are guided by perceptions of organizational culture, attempts to aggregate (or select among) internal interests, or some other factor. Indeed, these choices might be influenced by a combination of factors because universities are organizations that seem uniquely resilient in their capacity to retain a garbage-can model of decision making (Cohen et al., 1972; Musselin, 2007). Within such organized anarchies, perhaps ideas are important for policy making, in ways not yet illuminated by the literature? At the micro-level of organizational context, senior leaders might be susceptible to changes (or reinforcement) in how they think about internationalization, depending on whom they share ideas with. Hence, intra-organizational structures matter, not just for reinforcing cultural appropriateness or channeling powerful interests-also for sharing information and lesson-drawing.

There are reasons to believe that organizational context could be more important in Canada than elsewhere, due to the decentralized, delegated, and deconcentrated nature of university governance in Canada (King, 2019). 
Canadian higher education governance is decentralized in that there is no federal ministry of education, and jurisdiction over all aspects of higher education (except research funding) is a provincial competence. It is delegated in that decision-making power is in the hands of civil society actors, such as university leadership, with provincial governments in B.C. and Ontario not taking on a strong leadership role (Harmsen \& Tupper, 2017). This weak provincial government leadership has been exacerbated by diminished funding, with less than $50 \%$ of funding for operational expenses derived from provincial block grants, compared to $81.6 \%$ back in 1984 . Finally, Canadian universities have a culture of diffused authority at the organizational level, such that intra-organizational policy processes are characterized by deconcentrated power. The principle of institutional autonomy is matched by-and sometimes competes with-the principle of academic freedom, meaning that university administrators feel compelled to consult internal stakeholders when formulating policies. As a result of this decentralized, delegated, and deconcentrated governance, meso-level factors (such as a university's place in the $\mathrm{HE}$ sector) and micro-level factors (such as intra-organizational dynamics) could be especially important for explaining the internationalization of higher education in Canada.

We are still building our comprehension of the many factors that influence the development of university internationalization. To date, the emphasis has been on environmental context-appropriate given the multi-actor and multi-level governance of this organizational field. Less understood has been the influence of ideas, especially at the micro-level. More research on Canadian higher education is needed, especially comparative organization-level assessments of the "perspectives, practices, and experiences of participants engaged in internationalization" (Beck, 2012, p. 136; see also Jones, 2011). A case study of Canadian universities could provide us with a keener sense of the interaction of ideas and institutions at the intra-organizational level, and how these factors influence university-level internationalization.

\section{Theoretical Framework: Discursive Institutionalism}

Discursive Institutionalism (DI) is a framework for theorizing policy or institutional change that builds on the new institutionalisms while emphasizing the importance of ideas. Neo-institutionalisms emerged in the 1980s to theorize the importance of institutions as rules, norms, or structures that can constrain agency and impede change. Rational choice institutionalism understood institutions as the rules of the game that constrain powerful actors from realizing their fixed and given interests. Sociological institutionalism understood institutions in terms of cultural norms which channel actor behaviour. Historical institutionalists demonstrate how institutions can structure individual and collective agency through habituating processes like path dependence (Hall \& Taylor, 1996). However, these early neo-institutionalisms were better oriented to explaining stability rather than change. Explanations focused on institutions more so than ideas, although some analyses made room for ideas as external shocks that could induce institutional or policy reform (see Hall, 1993). Notwithstanding this limited treatment of ideas, "the institutional perspective is considerably more instructive as an explanation of the prospects for policy reform than as an explanation of the specific form that policy change takes" (Béland \& Hacker, 2004, p. 45). Thus, a theory about ideational power is more useful for explaining the content of policies or decisions-rather than just the likelihood of change.

Ideational power is here defined as "the capacity of actors (whether individual or collective) to influence actors' normative and cognitive beliefs through the use of ideational elements" (Carstensen \& Schmidt, 2016, p. 320). DI does not treat ideas as abstract entities disembodied from actors and their interactions, instead recognizing that social and political actors shape ideas through discourse (Hay, 2011; Schmidt, 2008). Indeed, "the best ideational analysis always begins and ends with the ways in which concrete actors think and talk about the world" (Béland, 2019, p. 4). This does not purport that ideational power entails strict causality, but rather, it demonstrates a logic-of-interpretation which helps to explain decision-making processes "by showing that someone arrives at an action only through one interpretation of what is possible and/or desirable" (Parsons, 2007, p. 13). In other words, DI treats ideational power 
as the production of particular kinds of effects (such as the capacity of actors to determine or influence the conditions of their existence) rather than something that is synonymous with causality. In the case of higher education internationalization, discursive institutionalism can highlight the importance of ideas for the formulation of particular rationales for internationalization, rather than merely as a condition for policy and institutional change.

DI conceives of three types of ideational power, two of which are useful for this analysis: power through ideas and power in ideas (Carstensen \& Schmidt, 2016). Power through ideas refers to the discursive capacity of actors to persuade other actors to accept and adopt views of what to think and do. This is the most common treatment of ideational power for empirical studies using the DI framework, and has been used in the field of education to analyze curriculum policies (Nordin \& Sundberg, 2018; Wahlström \& Sundberg, 2018). For the present study, power through ideas corresponds to discursive content: the subtle change in rationales used for decision making in university-level internationalization. Key policy interlocutors can report on the tenor of discussions and on the exchange of ideas, and this evidence can be used to understand which rationales resonated or gained traction amongst decision makers at Canadian universities. Power in ideas refers to how political institutions structure and shape discourse, how they can determine which actors are influential, and why. This element of DI pays attention to how policy-making institutions create meaning for sentient agents-institutions are internalized meaning-makers and not just external constraints for policy actors (Schmidt, 2011). In the present study, power in ideas refers to the discursive community: who is involved in the discussion and the types of discourse this entails. For simple polities, authority is hierarchical, such that policy discourses become communicative. After limited consultation, governments decide and then communicate policy rationales to stakeholders and the general public. In more complex polities (like Canada), governance is flatter and less hierarchical. In these institutional settings, the discourse is more coordinative: policy actors coordinate agreement amongst themselves about which ideas are most salient for policy making (Schmidt, 2008). Because government is just one among many policy actors in Canadian $\mathrm{HE}$, government rationales are expected to be less domineering. Yet the degree to which government policies matter could well be the result of the informational resources at hand within a given organization. In effect, the discourse community delimits the hegemonic power of decision makers to attend to the ideas of some actors and ignore others. A less developed discourse community is more likely to abide governmental policies during their decision-making process. Moreover, the concept of a discourse community can help us understand how "an idea whose time has come" becomes policy, without recourse to serendipitous "windows of opportunity" (Kingdon, 1984). The DI framework explicitly theorizes ideational power through discourse, and it suggests why certain discourses are capable of opening windows of opportunity in order to shape internationalization.

Discursive Institutionalist studies are characterized by four elements: (1) the content of ideas, (2) the interactive process of ideational communication-how ideas are exchanged and modified by discourse, (3) the institutional structures of discourse, and (4) insights into the dynamics of institutional change (Schmidt, 2010). These elements have been deployed here, in order to understand the ideational context behind internationalization at Tier 1 and 2 universities in Ontario and British Columbia. The first and fourth elements help us conceptualize the outcome and inform us as to why discourses can be powerful. Discourses on internationalization have subtly changed over the past decade, such that certain rationales have increasing influence over the direction of university-level decision making in this area. The second and third elements are theorized as features of the intellectual environment for decision making (although neither discourse nor ideas are posited as the sole proximate cause for agenda setting). This informs us as to why certain actors can be powerful within a discourse community. A preliminary proposition in this analysis is that governments are becoming marginal actors within Canadian discourse communities on HE internationalization. Senior leadership at universities are aware of government ideas regarding internationalization, yet they are becoming less responsive to them. Furthermore, the degree to which a university aligns to government internationalization policies will depend somewhat on the development of a university discourse community regarding internationalization. Universities that were early institutionalizers of internationalization (such as having well-resourced International Offices or being among the first movers for developing a formal internationalization strategy) are more likely to generate their own internationalization rationales rather than 
dovetail with government thinking. This is not intended as a causal theory which claims that discourses determine policy. Rather, it is a descriptive theory about the importance of discourse communities for generating and shaping internationalization rationales, within a subset of Canadian universities.

\section{Methodology}

For Discursive Institutionalism, research typically involves an evaluation of who talks to whom, about what, when, how, and why (Schmidt, 2011). This approach lends itself to qualitative methods and structured case comparisons, rather than a large- $\mathrm{N}$ quantitative analysis. Furthermore, epistemological commitments and methodological choices have become more pluralist over time. Whereas early DI studies were epistemologically positivist-using methods like process-tracing to try to control for non-ideational variables-Vivien Schmidt (2015) has more recently pointed out the validity of constructivist epistemologies and interpretive methods for understanding the power of ideas and discourse. Institutions and ideas are social constructs, and so the actors that use them can be a source for understanding their meaning and construction. As such, the present study adopts a qualitative case study approach, as well as interpretive methods for generating evidence.

With 95 public universities in Canada (not to mention scores of colleges and other institutions of higher education), a qualitative study of every institution's discourse on internationalization would be too resource-intensive. Instead, I examine a truncated sample that captures key dynamics at one end of the organizational field. This study examines a sub-set of Canadian universities which are comparatively advanced in their institutionalization of a global engagement ethos. The provinces of British Columbia and Ontario have the largest share of inbound international students compared to other regions of Canada, as well as the largest proportion of international students in proportion to their domestic student populations (Canadian Bureau for International Education [CBIE], 2015; Sá \& Sabzalieva, 2018). Furthermore, the experiences of these two provinces-and Ontario especially—has been shaping internationalization across Canada (Scott et al. , 2015). Within the two provinces, the comparison was structured around higher education institutions with similar characteristics and systematic differences. The sample was 16 universities from among Tier 1 research-intensives and Tier 2 comprehensives (Maclean's, 2019). From Ontario, this included the University of Toronto, Queen's, McMaster, the University of Western Ontario, Waterloo, York, Ryerson, Windsor, Guelph, and Wilfrid Laurier. For British Columbia, it included the University of British Columbia (UBC), Simon Fraser University (SFU), the University of Victoria, the University of Northern British Columbia (UNBC), the University of the Fraser Valley (UFV), and Thompson Rivers University (TRU). Interestingly, patterns emerged based on the "community" orientations of universities. High-ranked Tier 1 universities (UBC, Toronto, Queen's, McMaster, and Western) typically compared themselves to-or aspired to be-global universities that orient themselves within an international reputational field. Tier 2 universities and Tier 1 universities lower in international rankings (SFU, Victoria, York, Ryerson, and Waterloo) have been more inclined to relate to each other given a national orientation; they have a global dimension but are not yet well known outside of Canada. The third group of universities are regionally-oriented because they are located in less populous regions and have historically been concerned with serving the local community (Windsor, Guelph, Wilfrid Laurier, UFV, TRU, and UNBC). The shortcomings of this comparative-organizational approach are overcome by adopting both a bottom-up (institutional) lens and a top-down (sectoral) lens (Knight, 2004; for critiques, see Robertson et al., 2012).

Data collection involved traditional methods for qualitative research: interviews and document analysis (Yin, 2014). I conducted semi-structured interviews with high-level administrators at each university. The interviewees were selected based on their institutional positions, deemed critical for internationalization by expert informants at the Canadian Bureau for International Education. The interviewees had various titles (Assistant Vice-President International, Vice-Provost International, Director of the Internationalization Office, etc.), but had in common the responsibility for producing internationalization strategies, as well as intimate knowledge of the processes by which these plans were developed. I anonymized interviewees at their request. The interview transcripts were evaluated using manifest analysis: rich descriptions of what the informants actually reported, staying close to their actual words and explanations of 
meaning (Bengtsson, 2016; Berg, 2009). Interview data was corroborated using evidence from public-facing strategy documents, as well as through member checks with interviewees (Lincoln \& Guba, 1985). In terms of transferability, the sample size (16 universities) is sufficient to anticipate similar findings in similar casesalthough extending the sample would verify this (see conclusion section of this article). Overall, triangulating within-case and cross-case evidence strengthens the trustworthiness of the findings and generates confidence in the validity and reliability of the data (Yin, 2014).

\section{Find ings: Internationalization Dis- courses at Universities in B.C. and Ontario}

Interviewees were asked about topics of conversation which mattered most during formulation of internationalization strategies, such as their university's overall mission, market competitiveness, or government mandates. Interviewees were also asked about which actors were most influential for providing meaning to internationalization efforts, such as faculty, students, staff from the international office, other types of university administrators, or government. The purpose for this line of questioning was twofold. First, to establish which ideas had been emergent in discussions about internationalization-and if discourses or rationales had changed over time. Second, to identify "transmission belts for ideas" from one collective actor and another, and if there was "an organizational structure or social interaction through which information or argumentation was likely to have been transmitted to authoritative actors" (Jacobs, 2014, p. 66). The findings are elaborated below.

\section{Discursive Content}

For a number of Canadian universities within this subset, there has been a subtle discursive shift in the rationales for internationalization. During the 2000 s and early 2010s, decision makers discussed internationalization largely in terms of environmental context, and through a paradigm of competitiveness. More recent internationalization discourse has centred on organizational context, and the sense of social responsibility that a university has towards its place in the higher education communi- ty, and towards communities within the university itself. Interviewees at globally- and nationally-oriented Canadian universities reported that new rationales had gained traction during recent decision-making fora on internationalization. The most persuasive discussions were no longer about market share or reputational ranking, as had been previously. Now, the more resonant ideas emanated from discussions about the university's place, purpose, and community. Not to suggest that competition is no longer a powerful idea within internationalization discourses-indeed, it remains an important rationale, especially at regionally-oriented universities. Furthermore, there are still strong incentives to consider the broader environmental context, accompanied by discussions about how global competitiveness can be hindered or harnessed by effective internationalization. However, at several universities, talk of the "market" has been eclipsed by discussions about organizational context. It seems as if university decision makers are increasingly asking their colleagues and subordinates: if markets matter, then how do they matter to us? Moreover, power emanates from these "new" ideas. ${ }^{3}$ Their proponents try to ensure that they manifest in public justifications for internationalization. With some exceptions (such as Toronto and Waterloo), the globally- and nationally-oriented universities have seen a subtle paradigm shift in their most recent internationalization strategies: moving away from market rationales and towards notions of citizenship and community. The regionally-oriented universities (Guelph, Wilfrid Laurier, UNBC, Windsor, UFV, TRU) still adopt a market understanding of internationalization in both discourse and policy. Some universities in this sub-set continue to conceptualize internationalization predominantly in terms of a logic of competition, yet, by 2019, several of Canada's Tier 1 and 2 universities have begun to adopt more of a social responsibility rationale for internationalization.

When asked about their most recent internationalization strategy, several interviewees claimed that the more comprehensively discussed ideas pertained to their specific organizational principles or their identity as a public university. The global group of universities had a strong sense of public service, and responsibility to local and global communities. One interviewee from a "global" university commented that 10 years ago, high levels of international student recruitment and concern over rankings preoccupied their internationalization ef- 
forts, but their priorities had shifted (Interview 1). The same interviewee then discussed the importance of their service philosophy, and how this "butt[s] up against the idea of reputation and rankings" (Interview 1). Although there was variance in the principles themselves, many referred to being principles-based when creating or updating their internationalization strategy (Interviews $7,8,9)$. Universities with national or regional orientations also had clear sensibilities regarding mission and purpose, referring to core (and for some, foundational) values, such as inclusion (Interviews 12, 15). One went on to say,

...you hear [the federal government] speak of global engagement as part Canada's future prosperity and competitiveness, acquiring the necessary intercultural skills to remain globally competitive, and so on... [our university] is not excluded from this as a driver... but [we have] maintained a focus on social development, academic development and especially student experience. That is very much a part of [our] culture, and not simply recruitment. You can hear that in statements made by our senior leaders, but also [see it] in the numbers: our university has about $7.5 \%$ of our student population as international, and there is no perceived need to...make those numbers higher. (Interview 15)

When asked about the primary ideas informing internationalization, another interviewee replied, "you need to know who you are" (Interview 16). If Canadian universities were historically driven by neo-liberalism or other versions of a competitiveness paradigm, many were now aware of its dangers. Leadership at universities in this sample-and especially universities with a global or national orientation-looked more towards their own internal mandates to understand internationalization. It seems that the maturation of internationalization as a core strategy has been accompanied by greater need to understand one's own organizational identity and context.

However, a discourse around competitiveness and the importance of markets still retains moderate influence among these Canadian universities, and more so for regional universities. Smaller universities have encountered more acute financial pressures, not least because they depend on undergraduate tuition fees to remain viable. They face decreasing enrollment of do- mestic students, and "big gaps in our balance sheet" (Interview 14). One regional university acknowledged the benefit of cultural diversity, but "if anyone tells you they don't recognize the economic benefits of international students, I suggest they are not telling the whole truth" (Interview 5). Indeed, another leader at a regional university said about their internationalization strategy: "the primary driver is financial...Some institutions speak about preparing global citizens, but I don't think our lens has evolved to that stage yet" (Interview 14). Universities with a national or global orientation also acknowledged the importance of being competitive: "reputation matters...we don't have to do much to attract the best and brightest [Canadian] students because reputation can be self-perpetuating. But internationally? Nobody has heard of us! This is a problem, because higher education is becoming increasingly international" (Interview 9). A competitiveness paradigm, whether this means within a reputational market or a market for international students, will likely always have some place in internationalization rationales.

Yet the concern over competitiveness has become muted over time. An interviewee from a national university reflected on the late 2000 s as a period when there was greater pressure to recruit international students (Interview 2). Others referred to early marketization as affording them the luxury to now set other priorities: "certainly, in the late 1990s and early 2000s, [our university] had to look to international students as a way of being able to support the cost of running the institution. But this created a new milieu" (Interview 1 ). For some, the market dynamics merely switched from growth to diversification of international student recruitment (Interview 10). But others echoed the following: "there are many external forces that drive internationalization...but [markets] are never the primary driver... That is very short-sighted and based only on present economic conditions" (Interview 12). Market dynamics and competitiveness are factors, but for a number of institutions in this sample, they are no longer the primary ideational drivers for internationalization.

\section{Discourse Communities}

The discourses above are products of discourse communities that discuss, debate, and decide on internationalization agendas. Discourse communities are structured relationships with institutional roots: some actors are 
systematically involved and very influential, while others are discounted and effectively excluded. Actors have power-in-ideas due to their position within discourse communities, and decision making in Canadian HE is characteristic of a complex polity where discourses must coordinate agreement amongst (many) actors rather than just communicate ideas from authoritative actors. First, a brief explanation of a typical policy-making process at these Canadian universities, with interviewees indicating minor variations on the following. University high leadership framed the overarching issues or questions, sometimes with reference to guiding principles. Next, the internationalization office or a steering committee would be charged with facilitating consultation and feedback from the broader university community. The process itself would vary, depending on mandate and (especially) on resources, but usually involved some combination of surveys, focus groups, town halls, online fora, and similar mechanisms. The targets for these were primarily internal: other administrators and staff, faculty, and, occasionally, students. Consultation could involve stakeholders from outside the university as well (i.e., provincial Minister, city council, local businesses, First Nations groups, etc.). External actors could also exert influence on university administration via the internationalization office, as these management professionals would be expected to learn about trends, new ideas, best practices, government policy, and so on. It is not that internal actors consider only the organizational context, but rather, that universities have significant latitude to determine their own course of action (regarding internationalization, at least) and internal actors have a better understanding of this context. Moreover, the delegated and deconcentrated nature of these discourse communities meant that internal actors were highly influential in the decision-making process.

Interviewees at the 16 universities were asked to comment on the influence of various sets of actors in the formulation of internationalization policy. These included: university leadership, faculty, students, experts from education-related national associations or international organizations, administrators from other universities, and the government (provincial and federal). All the interviewees suggested that university high leadership was critical, for one reason or another. ${ }^{4}$ Some university leaders simply reminded others in the policy-making process about overarching strategic plans (Interview 1), while other senior leaders initiated international policy development themselves (Interview 8). Leadership contributed cognitive rationales as well, in some cases demanding quantifiable metrics (Interview 9) and in others, defining the "domains we should be entering, and how we should engage internationally" (Interview 13).

Senior leaders at these universities could not "go it alone," making unilateral decisions about internationalization without consultation with other internal actors. Indeed, faculty were often a valuable resource, especially at the "global" universities: "the discourse is entirely internal...our researchers are so connected, globally, that we asked [them]...this drove a lot of our discussions about globalization" (Interview 1). In this sense, faculty members were ideational transmission belts connected to communities beyond the university, and even the very notion of internationalization was developed in consultation with faculty. Furthermore, faculty were consulted because they expected it: "[it took] about a year of consultation with all our faculties and schools-everything at [our university] needs to be bottom-up" (Interview 10). Students were much less involved in this discourse community, with some interviewees expressing regret that they could not or did not better engage the student body. Finally, middle management within international offices have had a growing role within these discourse communities. Like faculty, internationalization experts have been ideational transmission belts between intra-organizational and sectoral discourse communities. As they become more professionalized, they have also become more influential as generators of policy ideas and not just implementers of policy. As one interviewee observed: "the sector is maturing to a point where international administrators are increasingly an identified professional sphere of work...It is an interesting moment in higher education internationalization in that there is a growing sophistication and professionalization of this work, rather than just being an element of administration that falls to whoever has shown some interest" (Interview 13). Overall, the picture is one of a discourse community primarily defined by intra-organizational relationships: leaders led, but they also faced institutional mandates to consult with other internal actors.

The decentralized and delegated nature of the discourse communities meant that external actors were not very influential in the policy-making process. When asked if the government was a critical ideational driver 
for internationalization, interviewees were almost unilateral in saying no. One interviewee responded by saying: "I am just going to discount that right away. The federal and provincial governments have those plans, but I don't think they were key to any decisions we were making" (Interview 9). Others questioned whether government policies were even coherent, with one saying "there is nothing strategic in Ontario's internationalization strategy! It is 'policy-speak' at best" (Interview 14). Another suggested that government internationalization policies were Johnny-come-lately, and that universities were guiding government policy, not the other way around: "government strategies lag behind what universities are doing. Many universities were working on [internationalization] plans long before the federal or provincial government" (Interview 12). Some complained that government could even hinder university efforts at internationalization through funding cuts, or policies like the "head tax" on international students in Ontario (Interviews 7, 11, 14). ${ }^{5}$ As such, provincial governments influence university internationalization agendas through funding, not through policies explicitly about HE internationalization. Federally, it is immigration policy (and to a lesser extent, foreign diplomacy) that seem to matter. Early in the Harper administration, restrictive immigration policies meant that "it felt like [Canadian universities] were working against the tide" (Interview 7). But with recent changes to study permits and work visas, higher education "is becoming the principle channel for immigration to this country...the university is doing the social integration work that other organizations used to be doing... without compensation!" (Interview 2). Therefore, it has been immigration and funding policies-not internationalization policy-that have been the primary ways that governments influence internationalization. The regulatory environment can facilitate or constrain internationalization because it sets the legal boundaries for things like appropriate cost recovery mechanisms or immigration opportunities. However, according to university administrators responsible for developing internationalization strategies, government discourses about internationalization do not drive their policy choices nor strongly influence their internationalization rationales.

Indeed, the lack of coherent structure in the external policy space diminished the influence of all actors external to the specific organization. Universities with a global orientation have ignored federal and provincial governments, neglected external experts, and paid scant attention to what other Canadian universities are doing. Senior leadership have had their eyes on the global horizon and learned from (or competed with) other global universities. Universities oriented to the national context have also discounted government, yet leadership has paid attention to other national HEls for framing issues or background context (Interviews 2, 3). Universities with a regional orientation have paid closer attention to government policy, but rarely involved government directly in their own policy development. According to interviewees from these universities, leadership would have liked more involvement with (external) civil society, but their internationalization offices lacked resourcesthey "tend to be mostly operational, and staff are not very involved in research and reflection" (Interview 6). Another commented that "larger institutions can dedicate resources. For smaller institutions, like us, we must do this work off the side of our desks" (Interview 14). Overall, regionally-oriented universities were more attentive to government (and more to provincial than federal), nationally-oriented universities were more attentive to each other, and globally-oriented universities could afford to ignore government because they had the resources to develop policies internally, or pick and choose what they learned from the external environment. Across these 16 Canadian universities, external actors were not especially influential, possibly because none have been able to dominate and structure the national policy space.

\section{Discussion and Conclusions}

This study of 16 universities in British Columbia and Ontario suggests that the rationales for internationalization are changing. Some universities are increasingly looking within to contextualize their internationalization efforts, because their discourse communities are dominated by internal actors who are now predominantly concerned with organizational context. Undoubtedly, some of this looks like old wine in new bottles. Yet internationalization has also brought new ideas, such as inter-cultural dimensions to labour-preparedness, or notions of global citizenship. This research has illuminated trends in how internationalization is understood, described some factors that influence these rationales, and contributed to a better understanding of intra-organizational dynamics for internationalization. Moreover, these findings sug- 
gest two possible arguments about how internationalization ideas could emerge in the future.

Given the decentralized, delegated, and deconcentrated nature of university governance in Canada, it is perhaps unsurprising that university senior leadership can dominate discourse communities, or that they try to coordinate agreement amongst university stakeholders. For recent internationalization efforts, neither federal nor provincial governments were much involved in university-level discourses, with associations and other external experts also playing a somewhat marginal role. Government policies will likely always be declarations of intent rather than attempts to create a strong regulatory environment (even a "soft law" one). Universities in Canada are too accustomed to academic freedom and institutional autonomy to accept diktats from government, and it seems more likely that this ideational policy space will be filled by civil society actors, such as national associations or international organizations. This situation, however, could change. One possibility is that provincial governments will take a stronger leadership role vis-à-vis the CMEC, or individually. Provincial ministries have so far lacked the political will to coordinate discourses or structure discursive communities, but they certainly have some power to do so as the single largest funder of higher education institutions. In the words of one university administrator: "if you want to herd cats, move their food!" (Interview 15). Another possibility is that the federal government could be trying to structure a national policy space with themselves at the centre. There remains a lag between the university rationales and government ideas, but the most recent federal strategy suggests that government is trying to get out in front of these discourse communities (see Global Affairs Canada, 2019). This could be empirically tested by examining the ideational effects of the 2019 federal government strategy. If the federal government wishes to influence micro-level thinking, then establishing a national discursive community (brokered by the government) with clear and persuasive ideas could be an effective means to this end. Future research might focus on whether a change in the government's discursive content could also affect some change in discursive communities-in other words, if ideational power works in both directions.

Another possibility is that an ideational policy space (at either the national or provincial level) may never fully materialize. From these research findings, one could ar- gue that Canadian universities are increasingly looking inwards when they grapple with ideas about internationalization. Senior leadership at Canadian universities seem more attentive to their university's identity and principles than they were in the "early days" of modern internationalization (the 1990s and early 2000s, in this context). They also must consult with internal voices to better understand how these principles integrate with an internationalization agenda. Here, too, we might see change. Faculty might have previously complained about a lack of consultation, yet this situation might actually deteriorate as other internal actors gain more power in the discourse community. Students and (increasingly professionalized) internationalization officers are starting to be asked for their ideas and expertise. This also suggests further opportunity for research. A sample size of only 16 does not allow one to generalize about the structure of discourse communities for HE internationalization. The transferability of this theory might be tested by examining the intra-organizational dynamics of policy making at more and different types of Canadian HEls. Expanding the time horizon and sample size would give us a better sense of discursive power in the construction of university-level internationalization, and whether changes in intra-organizational dynamics affords opportunity for new actors to become ideationally powerful.

Clearly, internationalization is becoming increasingly institutionalized within Canadian universities. This institutionalization could entail some ossification in thinking, regarding the most persuasive ideas and the most influential actors. Yet the reverse might also be true: the more that internationalization becomes institutionalized, the broader the discourse communities could become. And with this, there could be more transmission belts for ideas regarding the internationalization of Canadian higher education.

\section{References}

Agnew, M., \& VanBalkom, W. D. (2009). Internationalization of the university: Factors impacting cultural readiness for organizational change. Intercultural Education, 20(5), 451-462. https://doi. org/10.1080/14675980903371324

Beck, K. (2012). Globalization/s: Reproduction and resistance in the internationalization of higher education. Canadian Journal of Education, 35(3), 
133-148. https://journals.sfu.ca/cje/index.php/cjerce/article/view/1077

Béland, D. (2019). How ideas and institutions shape the politics of public policy. Cambridge University Press.

Béland, D., \& Hacker, J. S. (2004). Ideas, private institutions, and American welfare state "exceptionalism": The case of health and old-age insurance in the United States, 1915-1965. International Journal of Social Welfare, 13(1), 42-54. https://doi.org/10.1111/ j.1369-6866.2004.00296.x

Bengtsson, M. (2016). How to plan and perform a qualitative study using content analysis. NursingPlus Open, 2, 8-14. https://doi.org/10.1016/j. npls.2016.01.001

Berg, B. (2009). Qualitative research methods for the social sciences (7th ed.). Allyn \& Bacon.

Boli, J., Ramirez, F. O., \& Meyer, J. W. (1985). Explaining the origins and expansion of mass education. Comparative Education Review, 29(2), 145-170. https://www.journals.uchicago.edu/doi/ abs/10.1086/446504?journalCode=cer

British Columbia Ministry of Education. (2012). British Columbia's international education strategy. https:/l www2.gov.bc.ca/assets/gov/education/post-secondary-education/international-education/internationaleducationstrategy web.pdf

Buckner, E. (2019). The internationalization of higher education: National interpretations of a global model. Comparative Education Review, 63(3), 315-336. https://www.journals.uchicago.edu/doi/ full/10.1086/703794

Canadian Bureau for International Education. (2015). A world of learning: Canada's performance and potential in international education 2015. https://cbie.cal wp-content/uploads/2019/01/A-World-of-LearningHI-RES-2015.pdf

Carstensen, M. B., \& Schmidt, V. A. (2016). Power through, over and in ideas: Conceptualizing ideational power in discursive institutionalism. Journal of European Public Policy, 23(3), 318-337. https:/l doi.org/10.1080/13501763.2015.1115534
Clark, B. R. (1983). The higher education system: Academic organization in cross-national perspective. University of California Press.

Council of Ministers of Education, Canada. (2011). Bringing education in Canada to the world, bringing the world to Canada: An international education marketing plan for provinces and territories. https:/l www.cmec.ca/Publications/Lists/Publications/ Attachments/264/COF Bringing Ed to Canada Eng final.pdf

Cohen, M. D., March, J. G., \& Olsen, J. P. (1972). A garbage can model of organizational choice. Administrative Science Quarterly, 17(1), 1-25. https://doi. org/10.2307/2392088

Cowin, J. R. (2017). Public policy and the structural development of postsecondary education in British Columbia, Canada, 1960-2015. University of British Columbia.

Crăciun, D. (2018). National policies for higher education internationalization: A global comparative perspective. In A. Curaj, L. Deca, \& R. Pricopie (Eds.), European higher education area: The impact of past and future policies (pp. 95-106). Springer, Cham. https://doi.org/10.1007/978-3-319-77407-7

Dimaggio, P. J., \& Powell, W. W. (1983). The iron cage revisited: Institutional isomorphism and collective rationality in organizational fields. American Sociological Review, 48(2), 147-160. https://doi. org/10.2307/2095101

Enders, J. (2004). Higher education, internationalisation, and the nation-state: Recent developments and challenges to governance theory. Higher Education, 47(3), 361-382. https://link.springer.com/article/10.1 023/B:HIGH.0000016461.98676.30

Global Affairs Canada. (2019). Building on success: International education strategy 2019-2024. Government of Canada. https://www.international.gc.ca/education/assets/pdfs/ies-sei/Building-on-Success-International-Education-Strategy-2019-2024.pdf

Government of Canada. (2014). Canada's international education strategy: Harnessing our knowledge advantage to drive innovation and prosperity. https:/l www.international.gc.ca/education/assets/pdfs/over- 
view-apercu-eng.pdf

Hall, P. A. (1993). Policy paradigms, social learning , and the state: The case of economic policymaking in Britain. Comparative Politics, 25(3), 275-296. https://doi.org/10.2307/422246

Hall, P. A., \& Taylor, R. C. R. (1996). Political science and the three new institutionalisms. Political Studies, 44(5), 936-957. https://doi. org/10.1111/j.1467-9248.1996.tb00343.x

Harmsen, R., \& Tupper, A. (2017). The governance of post-secondary education systems in British Columbia and Ontario: Path dependence and provincial policy. Canadian Public Administration, 60(3), 349-368. https://doi.org/10.1111/capa.12220

Hay, C. (2011). Ideas and the construction of interests. In D. Béland \& R. H. Cox (Eds.), Ideas and politics in social science research (pp. 65-82). Oxford University Press.

Helms, R. M., \& Rumbley, L. E. (2017). Global: National policies for internationalization - do they work? In G. Mihut, P. G. Altbach, \& H. de Wit (Eds.), Understanding higher education internationalization: Insights from key global publications (pp. 131-135). Sense Publishers.

Helms, R., Rumbley, L., Brajkovic, L., \& Mihut, G. (2015). Internationalizing higher education worldwide: national policies and programs (CIGE Insights). American Council on Education. https://doi.org/10.13140/ RG.2.2.12513.51044

Jacobs, A. M. (2014). Process tracing the effects of ideas. In A. Bennett \& J. T. Checkel (Eds.), Process tracing: From metaphor to analytic tool (pp. 41-73). Cambridge University Press.

Jones, G. A. (2011, January). Globalizing Canada's universities: An overview [Paper presentation]. The Meeting of the Ontario Confederation of University Faculty Association, Toronto, Canada.

King, C. (2019). Internationalisation of higher education in a Canadian context: Responses to the Bologna Process from Canadian universities. European Journal of Higher Education, 9(1), 58-72. https://doi. org/10.1080/21568235.2018.1561311
Kingdon, J. W. (1984). Agendas, alternatives, and public policies (1st ed.). AddisonWesley Educational Publishers.

Knight, J. (2004). Internationalization remodeled: Definition, approaches, and rationales. Journal of Studies in International Education, 8(1), 5-31. https://doi. org/10.1177/1028315303260832

Knight, J. (2014). Is internationalisation of higher education having an identity crisis? In A. Maldonado-Maldonado \& R. M. Bassett (Eds.), The forefront of international higher education: $A$ festschrift in honor of Philip G. Altbach (pp. 75-87). Springer Science \& Business Media.

Lincoln, Y. S., \& Guba, E. G. (1985). Naturalistic inquiry. Sage Publications.

Luijten-Lub, A., Van der Wende, M., \& Huisman, J. (2005). On cooperation and competition: A comparative analysis of national policies for internationalisation of higher education in seven Western European countries. Journal of Studies in International Education, 9(2), 147-163. https://doi. org/10.1177/1028315305276092

Maclean's. (2019). Canada's best universities by reputation: Rankings 2020. https://www.macleans.cal education/canadas-top-school-by-reputation-2020/

Marginson, S. (2013). We are becoming more global. In H. de Wit, F. Hunter, I. Johnson, \& H.-G. van Liempd (Eds.), Possible futures: The next 25 years of the internationalization of higher education (pp. 48-51). European Association for International Education.

Meyer, J. W., Boli, J., Thomas, G. M., \& Ramirez, F. O. (1997). World society and the nation-state. American Journal of Sociology, 103(1), 144-181. https:/l doi.org/10.1086/231174

Meyer, J. W., \& Rowan, B. (1977). Institutionalized organizations: Formal structure as myth and ceremony. American Journal of Sociology, 83(1), 340-363. https://www.jstor.org/stable/2778293

Musselin, C. (2007). Are universities specific organisations? In G. Krücken, A. Kosmützky, \& M. Torka (Eds.), Towards a multiversity? Universities between global trends and national traditions (pp. 63-84). Verlag. 
Nordin, A., \& Sundberg, D. (2018). Exploring curriculum change using discursive institutionalism - a conceptual framework. Journal of Curriculum Studies, 50(6), 820-835. https://doi.org/10.1080/00220272.2 $\underline{018.1482961}$

Olssen, M., \& Peters, M. (2005). Neoliberalism, higher education and the knowledge economy: From the free market to knowledge capitalism. Journal of Education Policy, 20(3), 313-345. https://doi. org/10.1080/02680930500108718

Ontario Ministry of Advanced Education and Skills Development. (2018). Educating global citizens: Ontario's international postsecondary education strategy 2018. Government of Ontario. http:ll www.tcu.gov.on.ca/pepg/consultations/maesd-international-pse-strategy-en-13f-spring2018. pdf?utm source=Academica +Top+Ten\&utm campaign $=82$ c04fede1-EMAIL CAMPAIGN $20180703 \quad 05 \quad 50 \& u t m$ medium=email\&utm term $=0$ b4928536cf82c04fede1-51971833

Parsons, C. (2007). How to map arguments in political science. Oxford University Press.

Redden, E. (2018, August 24). For international students, shifting choices of where to study. Inside Higher Ed. https://www.insidehighered.com/ news/2018/08/24/international-enrollments-slowing-or-declining-some-top-destination-countries-look

Robertson, S. L., Dale, R., Moutsios, S., Nielsen, G., Shore, C., \& Wright, S. (2012). Globalisation and regionalisation in higher education: Toward a new conceptual framework (Working Papers on University Reform No. 20). University of Aarhus. https://susanleerobertson.files.wordpress.com/2012/07/2012robertson-et-al-toward-a-new.pdf

Sá, C. M., \& Sabzalieva, E. (2018). The politics of the great brain race: Public policy and international student recruitment in Australia, Canada, England and the USA. Higher Education, 75, 231-253. https:/l doi.org/10.1007/s10734-017-0133-1

Schmidt, V. A. (2008). Discursive institutionalism: The explanatory power of ideas and discourse. Annual Review of Political Science, 11(1), 303-326. https:// doi.org/10.1146/annurev.polisci.11.060606.135342
Schmidt, V. A. (2010). Taking ideas and discourse seriously: Explaining change through discursive institutionalism as the fourth "new institutionalism." European Political Science Review, 2(1), 1-25. https://doi.org/10.1017/S175577390999021X

Schmidt, V. A. (2011). Reconciling ideas and institutions through discursive institutionalism. In D. Béland \& R. H. Cox (Eds.), Ideas and politics in social science research (pp. 47-64). Oxford University Press.

Schmidt, V. A. (2015). Discursive institutionalism: Understanding policy in context. In F. Fischer, D. Torgerson, A. Durnová, \& M. Orsini (Eds.), Handbook of critical policy studies (pp. 171-189). Edward Elgar Publishing Inc.

Schulze-Cleven, T., \& Olson, J. R. (2017). Worlds of higher education transformed: Toward varieties of academic capitalism. Higher Education, 73, 813831. https://doi.org/10.1007/s10734-017-0123-3

Scott, C., Safdar, S., Trilokekar, R. D., \& El Masri, A. (2015). International students as "ideal immigrants" in Canada: A disconnect between policy makers' assumptions and the lived experiences of international students. Comparative and International Education/Éducation Comparée et Internationale, 43(3), 5. https://ojs.lib.uwo.ca/index.php/cie-eci/ article/view/9261

Seeber, M., Cattaneo, M., Huisman, J., \& Paleari, S. (2016). Why do higher education institutions internationalize? An investigation of the multilevel determinants of internationalization rationales. Higher Education, 72(5), 685-702. https://doi.org/10.1007/ s10734-015-9971-X

Slaughter, S., \& Rhoades, G. G. (2004). Academic capitalism and the new economy: Markets, state and higher education. Johns Hopkins University Press.

Snowdon, K. (2014). Internationalization in Canadian higher education: The Ontario Experience. In R. Bruno-Jofre \& J. S. Johnston (Eds.), Teacher education in a transnational world (pp. 367-389). University of Toronto Press.

Stensaker, B., Lee, J. J., Rhoades, G. G., Ghosh, S., Castiello-Gutierrez, S., Vance, H., Çalıkoğlu, A., Kramer, V., Liu, S., Marei, M. S., O'Toole, L., 
Pavlyutkin, I., \& Peel, C. (2019). Stratified university strategies: The shaping of institutional legitimacy in a global perspective. The Journal of Higher Education, 90(4), 539-562. https://doi.org/10.1080/002215 46.2018.1513306

Teichler, U. (2004). The changing debate on internationalisation of higher education. Higher Education, 48(1), 5-26. https://www.jstor.org/stable/4151528

Trilokekar, R. D. (2009). The Department of Foreign Affairs and International Trade (DFAIT), Canada: Providing leadership in the internationalization of Canadian higher education? In R. D. Trilokekar, G. A. Jones, \& A. Shubert (Eds.), Canada's universities go global (pp. 98-118). James Lorimer \& Co.

Viczko, M., \& Tascón, C. I. (2016). Performing internationalization of higher education in Canadian national policy. Canadian Journal of Higher Education, 46(2), 1-18. https://journals.sfu.ca/cjhe/index. php/cjhe/article/view/186014/pdf

Wahlström, N., \& Sundberg, D. (2018). Discursive institutionalism: Towards a framework for analysing the relation between policy and curriculum. Journal of Education Policy, 33(1), 163-183. https://doi.org/10. 1080/02680939.2017.1344879

Wildavsky, B. (2012). The great brain race: How global universities are reshaping the world. Princeton University Press.

Wilson, L. (2013). The internationalisation of higher education and research: European policies and institutional strategies. In H. de Wit, F. Hunter, I. Johnson, \& H.-G. van Liempd (Eds.), Possible futures: The next 25 years of the internationalization of higher education (pp. 28-33). European Association for International Education.

Yin, R. K. (2014). Case study research: Design and methods (5th ed.). Sage.

\section{Notes}

1 In 2014, the Department of Foreign Affairs, Trade and Development (DFATD) released its first internationalization strategy for higher education. Near the end of 2019, Global Affairs Canada (the current name for the DFATD) released a new strategy, with significant differences from the 2014 policy. This research pertains to university-level internationalization before the release of the 2019 federal strategy.

2 The international student population in Canada has grown by over $200 \%$ between 2000 and 2014, and increased by another $20 \%$ between 2016 and 2017, to a total of 370,975. Between 2012 and 2015, international student enrollments grew by $0.7 \%$ in the U.K., $18 \%$ in Australia, 22.5\% in the U.S, and $26.9 \%$ in Canada (Redden, 2018).

3 These ideas are not so much new, as they are renewed. Since at least the 1960s, Canadian universities have articulated some sense of social responsibility and global citizenship (Cowin, 2017).

4 The transition of internationalization from the remit of the VP Research (or in rarer cases, VP Students) to the provost's office (or a devoted AVP International) has been a key development, during the last few decades. By reporting to the provost, internationalization offices align to central functions of a university, and benefit from permanent resources.

5 Announced in the 2012 budget, this "head tax" refers to the removal of a $\$ 750$ annual subsidy provided by the Ontario government to Ontario HE institutions, for every non-PhD international student. Institutions were advised by the government that they might need to adjust their international student fees accordingly (Snowdon, 2014, pp. 377-378).

\title{
Contact Information
}

\author{
Conrad King \\ conrad.king@kpu.ca
}

